\title{
ON COLLABORATIVE REFERENCE AND THE ROLES OF THE INTERLOCUTOR
}

\section{Eduarda Calado Barbosa ${ }^{1}$}

\begin{abstract}
RESUMO
Neste trabalho, eu exploro a ideia de que a colaboração é requerida para a completude de atos de referir-se ao asserir conteúdo proposicional. Essa afirmação é sustentada por um marco empírico proposto primeiramente por HH Clark e seus coautores em fins dos anos 80 , mas que está correntemente sendo desenvolvido por pesquisadores nas áreas de sociologia, linguística e psicologia. Eu pretendo mostrar que, no que concerne às investigações filosóficas centradas na referência do falante, nós temos boas razões para supor que atos de referir são também direcionados ao ouvinte, como é sugerido por um trabalho recente de Kent Bach. Consequentemente, nós precisamos de uma teoria não-idealizada de asserções compatível com a observação empírica de como conversas diádicas reais funcionam. Para isso, eu enfoco em uma crítica à teoria da asserção de Stalnaker e ofereço formas de superar as dificuldades por ela trazidas, defendendo uma visão colaborativa da performance de asserções e dos atos de referência do falante.
\end{abstract}

Palavras-chave: Referência do falante. Asserção. Conversação. Colaboração.

\begin{abstract}
In this work, I explore the idea that collaboration is required for the completion of acts of referring by asserting propositional content. This claim is supported by an empirical framework first proponed by HH Clark and his coauthors in the late 1980s, but currently under development by researchers in areas such as sociology, linguistics and psychology. I intend to show that, in what concerns philosophical investigations focused on speaker reference, we have reason to suppose that speaker reference is also audience-directed, as suggested by Kent Bach in a recent work. Consequently, we need a nonidealized theory of assertions compatible with the empirical observations of how dyadic spontaneous conversations work. For that, I focus on a critique of Stalnaker's theory of assertion and offer ways to overcome the difficulties it brings up, defending a collaborative view of assertion-making and acts of referring.
\end{abstract}

Keywords: Speaker Reference; Assertion; Conversation; Collaboration.

${ }^{1}$ Doutorada em filosofia pela Universidade Federal de Minas Gerais, é bolsista do Consejo Nacional de Investigaciones Científicas y Técnicas (CONICET), no Instituto de Investigaciones Filosóficas, IIF-SADAF/CONICET, Argentina, onde é membro do BA-Lingphil. eduardacaladobarbosa@gmail.com. 
One of P.F. Strawson's most significant contributions to the study of reference is his emphasis on speaker reference. In a nutshell, he developed the idea that even though acts of referring depend first on the mastering of conventional rules of usage, they also depend on speakers recognizing circumstances of use. Strawson's view - put forward in his famous On referring (1950) - was later renewed by Bach (2008), who added to it the idea that usage is not only speaker-oriented but also audience-directed.

Bach classifies speaker reference as a four-place relation in which speakers choose expressions whose uses enable their audience to think about individuals. This view opposes the more traditional treatments of reference as either a binary relation between words (in what concerns semantics, their conventional meaning or logical form) and individuals or as a three-place relation between a word, a speaker who uses it and the individual it refers to. The view that reference is a binary relation can be found in Russell (1905), and the view that referring is a three-place relation, can be seen in Strawson himself. About his own position Bach affirms:

[...] a speaker, in choosing an expression to use to refer the hearer to the individual he has in mind, is in fact answering the following question: given the circumstances of utterance, the history and direction of the conversation, and the mutual knowledge between me and my audience, how informative an expression do I need to use to enable them to identify the individual I have in mind? Note that informativeness here can depend not only on the semantic information encoded by the expression, but on the information carried by the fact that it is being used. (BACH, 2008, p. 21).

Bach approaches reference in terms of acts of referring. Hence, in his view, reference is not described in general abstract terms, but with attention to what agents do when they intend to refer in conversations. I believe this is a more empirically adequate standpoint since most acts of referring are interactive and involve conversational exchange. An idealized and generalist approach to reference has many explanatory merits, but, here, I will adopt a criterion of empirical adequacy and commit to the prima facie assumption that empirical adequacy is advantageous in accounting for the workings of ordinary language and its usage.

My purpose will be to explore the common denominator between Bach's Strawson-inspired view and the idea that reference is collaborative, 
which is in consonance with sociological and developmental studies in language use, as remarked by Clark \& Wilkes-Gibbs (1986). I will begin with an overview of speaker reference. In section 2 , I present the idealized view of assertion and how it impacts theories of reference. I will finish, in section 3 , by pointing out how the problems raised by the idealized view can be solved by theories that privilege a collaborative view of reference that emphasizes the role of interlocutors.

\section{A brief comment on the relevance of the Strawsonian notion of speaker reference}

It is true that criticism of the notion of singular reference (reference to individuals) as a property of expressions has been a well-established position in the philosophy of language at least since the 1950s and 60s. This criticism was settled on the assumption that reference and truth-value, as semantic properties, are sensitive to pragmatic aspects and, therefore, should not be understood as properties of words. Strawson $(1950 ; 1954 ; 1964)$ was one of the predecessors of this idea.

It can be said that Strawson contributed to the discussions about reference with the acknowledgement that what is encoded in the conventional meaning of a singular term - or uniquely referring expression, in his terminology 2 - does not suffice to explain its reference. It is important to briefly recall, however, that Strawson is dialoguing with Russell (1905) and his concurrent position about the semantics of singular terms - definite descriptions and proper names, in particular.

While Russell claimed that the logical forms of sentences with singular terms hide existential propositions that, when false, render the whole sentential complexes false, Strawson held that referring is not something that sentences "do"; only agents refer - more precisely, by applying the meanings of sentences to instances of use. In response to Russell's prediction about the effects that nonexistent referents have on truth-value attribution, Strawson chooses a clearly pragmatically oriented strategy. To use the now classic example of the definite description 'the present king of France',

\footnotetext{
2 The set of expressions that includes words that refer to individuals, such as proper names, definite descriptions, indexicals and demonstratives.
} 
Strawson argued that the definite description in question does not pick an individual in virtue solely of its meaning. Meaning serves to orient speakers on how to use the expression in the appropriate circumstances in order to refer. Thence, if one were to utter (1)

(1) The present king of France opened the 2016 Olympic Games in Rio.

given that, in 2016, France was a republic and thus had no king, the use of (1) would be spurious and would elicit intuitions of truth-value gap.

For Strawson, this result is due to the fact that the reference of the token of the definite description in (1) depends on use and not on its semantic properties as a type-expression ${ }^{3}$. The important opposition, here, is between meaning and usage.

In this special sense of "mean", it is people who mean, not expressions. People use expressions to refer to particular things. But the meaning of an expression is not the set of things or the single thing it may correctly be used to refer to: the meaning is the set of rules, habits, conventions for its use in referring. (STRAWSON, 1950, p. 328)

Strawson then represents an important milestone in the recent history of philosophy of language: he helped to shift the emphasis of theories of reference from word reference to speaker reference. Strawson was pivotal in making it possible for theorist of reference to focus on agential aspects. We must not forget other very important contributions, coming from Grice (1967) and Austin $(1962 ; 1979)$, with the concepts of speaker meaning and of performative speech acts ${ }^{4}$, of course, but, here, my purpose is to highlight only Strawson's contribution as it paved the ground for Bach's view.

Now, unlike Strawson, Bach includes interpersonal elements in his theory of speaker reference. In taking a closer look at how agents refer in the fundamental site of the use of language, conversation, he began to de-

\footnotetext{
${ }^{3}$ See Strawson (1950) for more about the distinction between use, type-expression and occurrence of the type-expression.

${ }^{4}$ Grice defines speaker meaning as different from sentence meaning. While the former depends on communicative intentions, the later depends on the syntactic-semantic profile of linguistic expressions. Austin, on his turn, advanced the influent framework of speech act theory. In particular, he explores the idea that speakers can do more with words than just asserting. They can perform acts like giving orders, making promises, etc.
} 
fend that acts of referring are not static and/or individualist. Rather, they are dynamic and interpersonal.

\section{The idealized view of asserting and referring}

As we saw in the previous section, Strawson was responsible for introducing the notion of speaker reference to the philosophical discussion about reference. Nevertheless, he did not put much effort in offering a robust theory of asserting that, like his theory of reference, also highlighted the role of speakers in language use. We can find one such a theory in the works of Stalnaker, though. Assertions are defined by Stalnaker (1978; $1999 ; 2002)$ as speech acts that contribute with new information to the contexts in which they are performed. Contexts, on their own turn, are represented in terms of presupposed information. For Stalnaker (1999), a context corresponds to the common ground of assumptions shared by the participants in each conversation. The success of a new assertion then depends on how the participants react to adjusting the common ground with the new information (with accommodation or rejection ${ }^{5}$ ).

There is no doubt that Stalnaker's theory represents some progress in what regards the acknowledgement of pragmatic and interpersonal aspects involved in asserting. Assertion is portraited in his theory as something a speaker does, and an interpreter evaluates. The interpreter has a fundamentally normative role: she evaluates if an assertion does not contradict previous propositional commitments that are shared by the participants in the conversation. Her only possible moves then are to either accommodate the new contribution or to reject it.

In the Stalnakerian-framework, interpreters receive complete assertions as inputs. In the case of acts of referring by means of asserting, they determine the reference and then deliver an attitude of acceptance or rejection to the assertion as the output. Such a description of the role of interpreters has been criticized by authors such as Clark \& Wilkes-Gibbs (1986) who point out that it is built on an idealization of how agents interpret assertions and acts of referring, one that mimics a literary model. They affirm:

\footnotetext{
${ }^{5}$ If participants accept the new assertion as an adequate contribution or reject it on the grounds of informational discrepancies, irrationality or contradiction.
} 
Traditionally, philosophers, linguists, and psychologists have presupposed what might be called a literary model of definite reference. Speakers refer as if they were writing to distant readers. When Elizabeth selects the noun phrase the clown with a red nose in talking to Sam, the assumption is that she intends it to enable him to identify the clown uniquely. She satisfies her intentions by issuing the noun phrase. Her act of referring is cotemporal with that noun phrase, beginning with the and ending with nose. Further, she retains complete responsibility and control over the course of this process. Sam hears the definite description as if he were reading it and, if successful, infers the identity of the referent. But his actions have no bearing on hers in this reference. (CLARK \& WILKES-GIBBS, 1986, p. 3).

Clark \& Wilkes-Gibbs (1986) claim that Stalnaker conceives of assertions as idealizations because he neglects the underlying division of labor between speaker and interlocutor in the actual production of complete assertions, one that can be observed in spontaneous dyadic conversations.

As they argue, in a real conversation, the realization of an assertion depends on mechanisms of coordination maintenance: techniques of synchronization, turn taking and back-channel responses (such as, 'uhum', 'hum') that signal positive verdicts for continuation'. Take the following transcription of a spontaneous conversation between a speaker A and an interlocutor B - taken from Jefferson (1973) - as an example of the kind of evidence used by Clark \& Wilkes-Gibbs:

A. I heard you were at the beach yesterday. What's her name, oh you know, the tall redhead that lives across the street from Larry? The one who drove him to work the day his car I/ was-

B. Oh Gina!

A. Yeah Gina. She said she saw you at the beach yesterday.

A indicated he would go on until B identified the referent. Indeed, he stopped at B's interruption and completed the process by confirming B's identification with Yeah Gina.

(CLARK \& WILKES-GIBBS, 1986, p. 8).

The fragment shows one of the mechanisms to establish understanding that speakers use systematically when referring by means of asserting a certain content. It shows that the interlocutor has an active role and collabo-

\footnotetext{
${ }^{6}$ Conversational participants have techniques like head nodding, utterance initiation and finalization to mark turns, repairs. Cooperative participants act in ways that manifest their engagement in the conversation.
} 
rates with the speaker in accomplishing her communicative goal of referring. And there are plenty of other good examples provided by research in various areas of language studies today ${ }^{7}$. These evidence points at problems in Stalnaker's view. Firstly, because the interlocutor has more than a normative role. She has a collaborative role in the completion of the assertion. More, they show that assertions require coordination of tasks to be produced in the first place. Consequently, an act of referring by asserting will require that the speaker and the interlocutor establish a mutual understanding regarding to whom the speaker wishes to refer. The Stalnakerian view of asserting and referring seems then to be beneath some expectations of empirical adequacy. I will discuss this last claim in what remains of this section.

\subsection{The problem with the idealized view of asserting and referring}

As we saw, according to critics of the Stalnakerian theory of assertion, such as HH. Clark himself (in Clark (1985)), Clark \& Wilkes-Gibbs (1986), but also Goodwin (1981), the endorsement of Stalnaker's view brings unwanted consequences for theorists of reference for at least three corelated reasons:

i. Interchange is the primary way in which language is acquired. Sociological and linguistic ${ }^{8}$ research has found that every day illocutionary acts are frequently incomplete and only partially understood until correction is provided. Thus, a view of conversations as a succession of complete acts that are understood and then either accommodated or rejected by interlocutors mimics a literary model that does not reflect the actual use of language.

ii. A model that takes assertions as complete acts performed by one agent fails to account for the role of the interlocutors in acts of asserting.

\footnotetext{
${ }^{7}$ See Drew (1997), Lerner (2004) and Kitzinger (2013). It is in fact lamentable that these observations and their philosophical consequences have received little attention from mainstream philosophical investigations on pragmatics in the past.

8 See Jefferson (1973) and Glucksberg; Krauss; Higgins (1975).
} 
iii. Stalnaker's theory of assertion does not offer an empirically adequate view of acts of referring.

To sum up, the essential problem with the idealized view of referring would be its neglect of the collaborative nature of asserting and referring. But Clark and Wilkes-Gibbs do not limit their job to pointing out problems. They also offer a defense of what they call the collaborative view of reference, as an alternative that suppresses the consequences of the above-mentioned problems. In the last section of this paper, I will present this collaborative view and try to show how it helps us deal with i., ii and iii.

\section{The collaborative view comes to the rescue}

The criticism directed at Stalnaker's theory of assertion by Clark \& Wilkes-Gibbs is based on the idea that Stalnaker has an idealized literary model of speech act performance that brings unwanted consequences for theories of speaker reference. In the previous section, I presented the three main problems with this idealized view. Here, I will focus on each one of them and present the theoretical resources provided by collaborative views of asserting and referring that help overcome these difficulties.

Let us start with the problem in ii: a model that takes assertions as complete acts performed by one agent fails to account for the role of the interlocutors in acts of asserting. When we talk about interlocutors having many roles in asserting, we have one thing in mind: asserting is a coordinated task that requires a division of labor between speaker and interlocutor. Think about any other coordinated task. A simple everyday activity, like moving a couch from one place to another with your roommate or taking a walk with a friend. In both cases, the pairs coordinate their actions because they have a common goal. It requires that they attend to each other's movements, pace, trajectory etc. In a collaborative view of asserting and referring, something similar happens. Take the extract below into consideration again:

A. I heard you were at the beach yesterday. What's her name, oh you know, the tall redhead that lives across the street from Larry? The one who drove him to work the day his car I/ was- 


\section{B. Oh Gina!}

A. Yeah Gina. She said she saw you at the beach yesterday.

A has a plan of referring to Gina and B is being collaborative. A is trying to say that Gina saw B at the beach the day before, but A and B's informational statuses about Gina need to be first adjusted to allow for the completion of A's communicative intention of asserting that Gina saw B at the beach. This general idea of adjustment is present also in Kepa Korta and John Perry's Critical Pragmatics (2010). They affirm: "We want to understand complicated actions and activities as cases of rational, purposeful action, that is, as things that are done in pursuit of goals, and are sensitive to one's beliefs.” (KORTA \& PERRY, 2011, p.35).

The authors explore the concept of plan of referring: the joint effort in which a speaker and an interlocutor (or more) have different but collaborative and coordinated tasks to achieve the general goal of information exchange. According to Korta \& Perry, the speaker's plan of referring to $x$ (an individual) involves taking the interlocutor's informational status into consideration, warranting that corrections, revisions etc. are possible. Their framework then seems at first sight compatible with the requirements of a collaborative view of singular reference. It predicts the division of labor empirically observed by Clark, Clark \& Wilkes-Gibbs and more recent works that follow the same framework. So, adopting a combination of Korta \& Perry and Clark and Clark \& Wilkes-Gibbs' ideas, instead of an idealized and individualistic view of asserting and referring, might help us deal with the problem in ii.

In what concerns i., I believe that the idea of cycles of acceptance developed by Clark \& Schaefer (1987) and Clark \& Wilkes-Gibbs comes in handy to solve potential difficulties. They define cycles of acceptance as follows:

The basic process, which might be called the acceptance cycle, consists of a presentation plus its verdict. Let $\mathrm{X}, \mathrm{y}$, and $\mathrm{z}$ stand for noun phrases or their emendations. A presents $\mathrm{x}$ and then $\mathrm{B}$ evaluates it. If the verdict is not positive, then A or B must refashion that presentation. That person can offer: a repair x', an expansion y, or a replacement $\mathrm{z}$. The refashioned presentation, whether $\mathrm{x}^{\prime}, \mathrm{x}+\mathrm{y}$, or $\mathrm{z}$, is evaluated, and so on. 
Acceptance cycles apply iteratively, with one repair, expansion, or replacement after another, until a noun phrase is mutually accepted. With that, A and B take the process to be complete [...]. (CLARK \& WILKES-GIBBS, 1986, p. 24)

Remember that the problem in ii. is that a view of conversations as a succession of complete acts that are understood and then either accommodated or rejected by interlocutors mimics a literary model that does not reflect the actual use of language. I believe that the concept of cycles of acceptance offers a theoretical tool to defend that acts of asserting should not be treated as complete inputs that deliver attitudes as outputs. Rather, it helps explain what is shown by empirical evidence, namely, that, in conversations, interlocutors have an active role in making communicative intentions comprehensive. If there is an informational discrepancy, the conversation does not stop with an attitude of rejection. The interlocutor is not a passive judge, she will collaborate simultaneously to help overcome such discrepancies by permitting self-corrections, hesitations etc., and cooperating with the speaker's role. The interpretation of the content of an assertion is, thus, processual and results from the cooperative effort of exchanging information by means of interacting conversationally.

Recall that the primary motivation to prefer a collaborative view rather than an idealized view of assertion is empirical adequacy. Now, we are in position to add another motivation: the success of collaborative views in explaining common phenomena of everyday communication, such as solving informational discrepancies. Empirical adequacy and intuitive appeal seem to be valuable theoretical advantages when choosing an orientation in studying natural languages. The difficulties brought up by i. can be dealt with, then, with the inclusion of more roles for interlocutors, as the cycles of acceptance framework suggests.

We will now conclude with the problem in iii., which relates to the impacts of a literary view of assertion-making for acts of referring: it seems that all that we have discussed so far suggests that Stalnaker's theory of assertion does not offer an empirically adequate view of acts of referring. Both the idea of plans of referring and of cycles of acceptance can be used to avoid this consequence. The authors behind these concepts show that we need to attend to the relevance of common knowledge and coordination for 
the determination of reference. If asserting is taken as collaborative, referring can also be seen as an essentially collaborative activity.

To conclude the case of the problem in iii., notice that Clark \& Wilkes-Gibbs' view of speaker reference is compatible with Bach's thesis that reference is a four-place relation. In the example of the conversation between $\mathrm{A}$ and $\mathrm{B}, \mathrm{A}$ (the speaker) uses the definite description 'the tall redhead that lives across the street from Larry', for example, to refer B (his/her audience) to Gina (the individual). Hence, empirical evidence from transcriptions of real dyadic conversation come to support Bach's claim that four elements are required for acts of referring. The common denominator between his philosophical account and Clark \& Wilkes-Gibbs' is, thus, their recognition of the role of interlocutors and the consequent rejection of an idealized speaker-oriented view of acts of referring in favor of a collaborative and audience-directed one.

\section{Conclusion}

It can be said that we have come a long way from theories centered exclusively in word reference to pragmatic theories of reference centered on speakers, like Strawson's (from section 1). In sections 2 and 3, I tried to argue that using the general insights motivated by developmental and sociological studies that investigate conversation, we find a reason to reject idealized views of acts of asserting and referring in favor of a collaborative view, in which coordination is a key factor and interlocutors have more than a normative role. A speaker might be aware of her own communicative intentions, but the actual production of an assertion is typically carried out simultaneously to its interpretation, with an asymmetric but still cooperative division of labor. This offers a fresh insight into language and communication with direct implications for philosophical theories of reference. All the roads lead to 'collaboration' and 'coordination' as essential words in talking about reference. 


\section{References}

AUSTIN, J. L. How to do things with words. Oxford university press, 1975.

AUSTIN, J. L. Philosophical papers, Oxford University Press, 1979.

$\mathrm{BACH}, \mathrm{K}$. On referring and not referring. Reference: Interdisciplinary perspectives, Ed. Jeanette Gundel and Nancy Hedberg. Oxford: Oxford U, p. 13-58, 2008.

CLARK, H. H.; SCHAEFER, E. F. "Dealing with overhearers." Arenas of language use, pp. 248-297, 1992.

CLARK, H. H.; WILKES-GIBBS, D. "Referring as a collaborative process." Cognition, vol. 22, no 1, pp. 1-39, 1986.

DREW, P. “'Open' Class Repair Initiators in Response to Sequential Sources of Trouble in Conversation." Journal of Pragmatics vol. 28, pp. 69$101,1997$.

GOODWIN, C. Conversational organization: Interaction between speakers and hearers. New York: Academic Press, 1981.

GRICE, H. P. William James Lectures. Harvard University, pp. 41-58, 1967.

GLUCKSBERG, S.; KRAUSS, R.M.; HIGGINS, E.T. "The development of referential communication skills". In F.E. Horowitz (Ed.), Review of child development research. Vol. 4, pp. 305-345, Chicago: University of Chicago Press, 1975.

JEFFERSON, G. "A case of precision timing in ordinary conversation". Semiotica, vol. 9, pp. 47-96, 1973.

KITZINGER, C. "Repair." In SIDNELL, J. \& STIVERS, T. (eds) The Handbook of Conversation Analysis. John Wiley \& Sons, Ltd, pp. 229-56, 2013.

KORTA, K; PERRY, J. Critical pragmatics: An inquiry into reference and communication. Cambridge University Press, 2010.

LERNER, G. H. "On the Place of Linguistic Resources in the Organization of Talk-in-Interaction: Grammar as Action in Prompting a Speaker to Elaborate." Research on Language \& Social Interaction vol. 37 (2), pp. 15184, 2004. doi:10.1207/ s15327973rlsi3702_3.

RUSSELL, B. “On Denoting”, Mind, vol. 14, pp. 479-493, 1905.

STALNAKER, R. C. 'Presuppositions', Journal of Philosophical Logic, vol. 2, pp. 447-457, 1973. 
Perspectiva Filosófica, vol. 45, n. 2, 2018

STALNAKER, R. C. 'Pragmatic Presuppositions', in Milton K. Munitz and Peter K. Unger (eds.), Semantics and Philosophy, New York University Press, New York, 1974.

STALNAKER, R. C. Assertion. Blackwell Publishers Ltd, 1978

STALNAKER, R. C. Context and content: Essays on intentionality in speech and thought., 1999.

STALNAKER, R. C. “Common Ground', Linguistics and Philosophy vol. 25, n.5-6, pp. 701-721, 2002.

STRAWSON, P. F. “On referring”, Mind, vol. 9, pp. 320-44, 1950.

STRAWSON, P. F. “A Reply to Mr. Sellars”, Philosophical Review, vol. 63, pp. 216-231, 1954.

STRAWSON, P. F. "Identifying reference and truth-values." Theoria vol.30, n. 2, pp. 96-118, 1964. 